\title{
Challenge to Integrate Different Fields
}

by

\section{Kohei TATEYAMA*}

この度, 衝撃部門委員会より推薦を頂き, 会員便り に執筆する機会を頂きました。まだ新米の教育，研究 者ですが, 大学生時代から現在までの研究や仕事に関 する紹介を交えて私の自己紹介をさせていただきます。

学部時代は, 山形大学工学部物質科学工学科に在籍 し，主に化学を学びました，小中高とずっと化学の実 験が好きでしたので, 大学で行う本格的な実験がとに かく楽しかったと当時を記憶しています。研究室配属 では微粒子や粉体を扱う研究室に配属になり, 機能性 粒子の合成や粉体の特性評価について研究を行いまし た。実験は好きでしたが，あまり学力が高くなく考え ることが苦手だったこともあり，卒業研究を形にする ためにとにかく手を動かし，多くの実験をこなしたこ とを覚えております。

大学を卒業後は, 陸上自衛隊幹部候補生として入隊 し，幹部自衛官として約 10 年間勤務しました。詳細は 割愛させて頂きますが, 武器や車両の整備部隊の隊長 として, 日々の訓練から演習場での野営, 災害派遣に 至るまで様々な業務を行っておりました。

その後, 2013 年に防衛大学校システム工学群機械工 学科に入校し, 小笠原永久先生と山田浩之先生の研究 室の大学院生としてメンバーに入れて頂きました．当 研究室では幅広い研究テーマを扱っていたことがとに かく印象に残っております。一例として挙げるだけで も, 金属の水素脆化現象の解明や材料の衝撃変形特性 の評価, 赤外線を用いた非破壊検査手法の開発, 微小 押込試験を利用した衝撃特性評価手法の開発等のテー マがあり，それぞれの研究報告のゼミだけでも非常に 刺激的でした。私には材料の衝撃変形特性の評価に関 するテーマを与えて頂き, 衝撃試験装置の作製から実 装, メンテナンスに至るまで衝撃工学研究分野の実験 に関するノウハウを学ぶことができました。この当時 の経験が, 現在の私の研究の土台となっております.

学位取得後は, 立命館大学理工学部の衝撃工学研究 室に助教として着任しました。現在 4 年目となります が, 渡辺圭子先生とともに研究室の運営に携わってお ります。「衝撃工学研究室」の名前からもわかる通り「衝 撃現象を扱う」という共通点はありましたが, 私がそ れまで行っていた衝撃とは異なるものでした. 私が扱っ ていた速度は数 $\mathrm{m} / \mathrm{s}$ から速くても数十 $\mathrm{m} / \mathrm{s}$ という速度
だったのに対して，当研究室では数百から数千 $\mathrm{m} / \mathrm{s}$ の いわゆる「Hypervelocity」を扱う研究が行われています. また, 当研究室で扱うテーマも実に様々で, 粒状物質 に対する飛翔体の衝撃貫入現象の解明や衝突誘起プラ ズマを利用した衝突部の温度測定, 磁気粘性流体やポー ラスマテリアルを用いた衝撃吸収システムの構築, マ グネット・コイル法と呼ばれる非接触式の挙動計測手 法の開発等に関する研究を進めております。ここで面 白いことは，これらの研究を進めるにあたり，「分野が 違うからもう使うことはないだろう」と思っていた学 部時代の化学実験や粉体の取り扱いに関する知識が非 常に役に立っていることです，小笠原・山田研で経験 した幅広いテーマに関する知見は言うまでもありませ ん. 化学も機械工学も結局は同じ工学部ですので完全 な異分野というわけではありませんが，全く関係ない と思っていた知識が結果的に融合して新たな学びとな ることを今，実感しております。

このように私は, 学部から就職を経て現在まで, 一 つの「専門」を一貫してきたわけではありません，当然， 信念をもって一つの専門を一貫して研究してこられた 方には知識・経験ともに遠く及びません。しかし，多 くのテーマに触れ研究以外においても幅広い貴重な経 験を多くすることができたことは，私の研究生活にお ける原点であり基盤となっております。今後は，さら に広範な分野にも興味を置き，工学システムとそれを 取り巻く環境との調和性の実現に向けて, 異分野の融 合を目指せればと考えております。

最後に蛇足ではありますが, 現在では料理・調理に 特に興味を持っております。もともと私にとって料理 は化学実験であり, 根拠希薄な思い付きでも様々な試 みをしては趣味として楽しんでいました。料理・調理 は様々な分野の知識の結晶であることから, これこそ 「異分野融合」が最も必要とされるテーマではないで しょうか. 研究分野として料理・調理と衝撃工学は無 縁に思えますが, すでに食感に関する研究や衝撃波を 利用した「爆破料理」に関する報告もあるように，こ の二つの分野が融合するテーマは決して突飛ではない ようです．料理・調理は一例ですが，枠にとらわれな い自由な発想で今後も楽しく研究生活を送りたいと 思っております。

†原稿受理 令和 3 年 4 月 7 日 Received Apr. 7, 2021 ○2021 The Society of Materials Science, Japan

* 正会員 立命館大学理工学部機械工学科％ 525-8577 滋賀県草津市野路東, Dept. of Mech. Eng., Ritsumeikan Univ., Nogihigashi, Kusatsu, 525-8577 